\title{
飼料用米・米粉用米の数量払い政策における標準単収值の設定実態とその課題
}

一地域農業再生協議会に対する全国悉皆調査からの接近一

\author{
小川 真如 1$) *$
}

\section{Distribution and Problem of Standard Yield Values in the Quantity Payment Policy of Rice, for Feed Rice and Rice Flour: Nationwide Survey Results for the Regional Agricultural Regeneration Councils in Japan}

\author{
Masayuki Ogawa ${ }^{1) *}$
}

In this study, a nationwide survey of standard yield values stipulating a subsidy system for quantity payments for feed rice and rice flour, has been conducted. There are three main findings. First, $61 \%$ of the regional agricultural revitalization councils have standardized the standard yields in their respective regions, with an average value of
$513.3 \mathrm{~kg} / 10$ a. Second, in some regions standard yield values have been set to multiple types, depending on local conditions. Third, a case study has revealed a regional approach to setting multiple standard yields, replacing the previous efforts of rice production adjustment.

キーワード：標準単収値, 数量払い政策, 飼料用米, 米粉用米, 地域農業再生協議会, 悉皆調査

\section{1. 課題設定と目的}

飼料用米と米粉用米に対する現行の政策的支援 は,「水田活用の直接支払い交付金による戦略作物助 成」(以下，「戦略作物助成」と略す.),「産地交付 金」,「県や市町村の単独助成」, の主に 3 つである. このうち, 戦略作物助成は, 最も金額水準が高く, 農業経営体による飼料用米・米粉用米の生産を成立 させる最も重要な経済的条件である.

戦略作物助成では，一括管理と区分管理という生 産方式があり，交付単価は標準単収値を用いた計算 式で決定される。一括管理の場合は，指定した圃場 から標準単収值の数量を指定の用途（飼料用，米粉 用）に出荷することで 80,000 円/10 a が支払われる. 指定した围場の収量が標準単收值に満たない場合に は, 他の圃場から生産した米による数量の埋め合わ せが必要であり，一方で収量が標準単収值を上回っ
た場合には，上回った数量を主食用米等として出荷 することができる．区分管理の場合は，標準単収值 の収量であれば 80,000 円 $/ 10 \mathrm{a}$ の交付金であるが，収 量に応じて数量払い（傾斜 167 円 $/ \mathrm{kg}$ ) される. 数量 払いは標準単收値の $\pm 150 \mathrm{~kg} / 10 \mathrm{a}$ まで設定されてお り，交付単価は 55,000 105,000 円/10 a である.

このように，飼料用米と米粉用米に対する戦略作 物助成では，一括管理と区分管理の生産方式の違い に関係なく，標準単收値が交付金額を規定している のである。

この標準単収値は，地域の合理的な単収に作況変 動（ふるい目 $1.70 \mathrm{~mm}$ 以上の当年単収 $\div$ ふるい目 $1.70 \mathrm{~mm}$ 以上の平年単収）を乗じて算出する。この 際，地域の合理的な単収の設定方法は各地域農業再 生協議会に裁量がある.

標準単収値に規定される交付金体系は, 2014 年産

1)一般財団法人農政調査委員会調査研究部; Policy Research Department, Agricultural Policy Research Committee, Inc.

* E-mail: ogawa.m@apcagri.or.jp 
からの数量払いに伴って導入されたものである.も ともと, 飼料用米や米粉用米の振興に当たって, 全 国統一的な単収水準も検討されたが，2013 年産まで は80,000 円/10 a の面積払いが行われた. こうした経 緯について大澤誠（2012 年当時, 農林水産省大臣官 房政策課長）は，「全国統一的な単収を設定したりし て基準をつくるということが現実に合らかどらかを 調べた結果，いま一つ自信がもてないといらところ ですので，当分の間は面積払いにしょうということ が考光方としてあったと聞いて扔ります」(全農林労 働組合, $2012 ：$ p. 23）と述べている.

また，研究では飼料用米について宮田（2010） が，面積払いが単収向上に結び付いていないことを 指摘した。政府は 2014 年度に数量払いを導入し， 農林水産省パンフレット「経営所得安定対策等の概 要」にて「努力が報われる仕組みだね！」等と示し ながら，単収向上が交付金増加につながる仕組みで あるとして数量払いの政策枠組みを説明してきた。

数量払いに伴い設定されることとなった標準単収 值であるが，標準単収值に着目した既往研究は手薄 である。

とはいえ，小川（2017）は，標準単収値の設定値 が飼料用米の收益性や，低単収圃場に打沙耕境变 動や地代に影響する可能性を指摘しており, 数量払 いが，捨て作りの防止や個別経営による単収向上の 努力を評価することを目的とするならば，制度運用 上，農業共済組合が保有する 1 筆単位の単収データ の活用が必要と指摘した。 また, 鵜川他 (2019: p. 64）は「数量払い方式の見直しでは標準単収のあり 方がポイントになると想定される」と言及している.

このように現行政策の評価・検討を行う上で, 標 準単収值のあり方は重要な論点の一つと考光られる が, 議論のベースとなる標準単収值の現状は, 公表 事項ではなく先行研究もないことから把握されてい ない。例外的に, 小川 (2017：p. 450）が「西日本 のある市で... [中略〕 ...全 101 区分（418～ $547 \mathrm{~kg} / 10 \mathrm{a})$ と $120 \mathrm{~kg}$ 以上の差を設けて中山間地域 と平場で公平な制度に修正している」と事例を指摘 しているが，全国的動向は明らかでない。

そこで本研究では, 地域農業再生協議会に対する 調査から, 標準単収値の設定状況を明らかにし, 現 行政策が現場段階でどのように運用されているのか
を明らかにし，標準単収値をめぐる問題の所在を析 出することを目的とする。

な打，各地域段階の農業再生協議会の呼称は多様 性があるが，本研究では表現を基本的に「地域農業 再生協議会」に統一し，例外として事例分析はそれ ぞれの組織名に従って表記する。

\section{2. 分析方法}

本研究では, 全国の地域農業再生協議会に対して アンケート形式の悉皆調査を行い，その結果を踏ま えて特徵的な調査対象については聞き取り調査を実 施し, 標準単収値の設定の現状を明らかにする。

アンケート調査は, 郵送アンケート方式によって 行い，農林水産省が公表する地域農業再生協議会の 全 1,471 空口に対して配布した。無効回答はなく, 有効回答 985（うち無回答は 91）であった。な拉, 有効回答数は合併前の地域農業再生協議会単位で回 答して提出された 2 件分，および，1つの空口で 3 つの地域農業再生協議会を担当しているケースから 回収した 3 件分を含む值である.

分析対象となる 985 の地域農業再生協議会につい て，標準単収値を統一して1つ設定している場合を 「統一設定」, 複数設定している場合を「複数設定」 として整理し，分析を進める.

回収されたアンケート調査票について，その数と 構成比を示すと，「統一設定」が $600(61 \%) ， 「$ 複数 設定」が 113 (11\%)，「その他」が 181 (18\%)，「無 回答」が 91 (9\%) であった

\section{3. 標準単収值の設定状況}

\section{（1）設定状況別の地域概況}

標準単収值の設定方法の差異について，水田面積 に着目して整理した（表 1)。本研究の分析対象で は, 飼料用米 $51,021 \mathrm{ha}$, 米粉用米 3,668 ha の生産地 域を捕捉しているといえる。これは全国の生産面積 85,000 ha の $64 \%$ に相当する.

分析対象について, 標準単収值の設定別にみると, 「統一設定」が生産面積でも大きな割合を占めて招り $71 \%$ である. 次いで「複数設定」が $26 \%$ あった。

前述したように，地域農業再生協議会数では「そ の他」と「無回答」が $18 \% ， 9 \%$ と無視できない割 合であったが，生産面積で整理した表 1 では，それ 
表 1．標準単収值の設定別にみた米粉用米・飼料用米の生産面積（2018 年度）（ha）

\begin{tabular}{lrrrrc}
\hline \hline & 飼料用米 & 米粉用米 & 飼料用米+米粉用米 & 全国シェア & 分析対象中のシェア \\
\hline 全国 & 80,000 & 5,000 & 85,000 & $100 \%$ & - \\
\hline 分析対象 & 51,021 & 3,668 & 54,689 & $64 \%$ & $100 \%$ \\
統一設定 & 36,563 & 2,070 & 38,633 & $45 \%$ & $71 \%$ \\
複数設定 & 12,960 & 1,454 & 14,414 & $17 \%$ & $26 \%$ \\
その他 & 1,038 & 128 & 1,166 & $1 \%$ & $2 \%$ \\
無回答 & 460 & 16 & 476 & $1 \%$ & $1 \%$ \\
\hline
\end{tabular}

資料：全国の值は農林水産省「2018 年産の水田に打ける作付状況」(2018年 9 月 15 日現在), 分析対象の値はアンケート調 査結果扣よび農林水産省「地域農業再生協議会別の作付状況」（2018 年 9 月 28 日）の值を積み上げて筆者作成.

表 2. 標準単収值（統一設定）と市町村別単収 $(\mathrm{kg} / 10 \mathrm{a})$

\begin{tabular}{|c|c|c|c|}
\hline & $\begin{array}{l}\text { 標準単収值（統 } \\
\text { 一設定）の地域 }\end{array}$ & $\begin{array}{c}2017 \text { 年産米単 } \\
\text { 収 (市町村) }\end{array}$ & $\begin{array}{l}2017 \text { 年産米単 } \\
\text { 収 (都道府県) }\end{array}$ \\
\hline データ数 & 590 & 1,549 & 47 \\
\hline 最小值 & 395 & 100 & 301 \\
\hline 最大值 & 663 & 683 & 629 \\
\hline 平均 & 513.1 & 508.3 & 515.4 \\
\hline 標準偏差 & 42.0 & 54.4 & 47.6 \\
\hline 変動係数 & 0.08 & 0.11 & 0.09 \\
\hline
\end{tabular}

資料：アンケート調査結果扣よび農林水産省「作物統計調 査」より筆者作成.

1）市町村は，「事実のないもの」扎よび「統計数值を公表 しないもの」を除く 1,549 市町村を対象とした.

ぞれ $2 \%, 1 \%$ と，極めて低い割合となっている.

これは，表に示していないが，「その他」とした地 域農業再生協議会 181 のらち，84\%に当たる 152 に おいて, 飼料用米や米粉用米の生産がないため設定 していないと回答をしていることからも確認できる. 同様に,「無回答」とした地域農業再生協議会の中に は, 飼料用米や米粉用米の生産がないため回答しな かったといらケースが多いものと考光られる.

以上より，2018 年産の飼料用米打よび米粉用米 は, 約 7 割が「統一設定」の地域, 約 3 割が「複数 設定」の地域で生産されたものと推定される.

\section{(2) 標準単収值「統一設定」の特徵}

統一設定の場合の標準単収値を, 市町村別と都道 府県別の米単収と比較して表 2 亿示した。

平均值は標準単收值が $513.1 \mathrm{~kg} / 10 \mathrm{a}$, 市町村別単 収が $508.3 \mathrm{~kg} / 10 \mathrm{a}$ ，都道府県別単収が 515.4 であり， その差は極めてわずかである。併せて，变動係数に も大きな差はみられない。

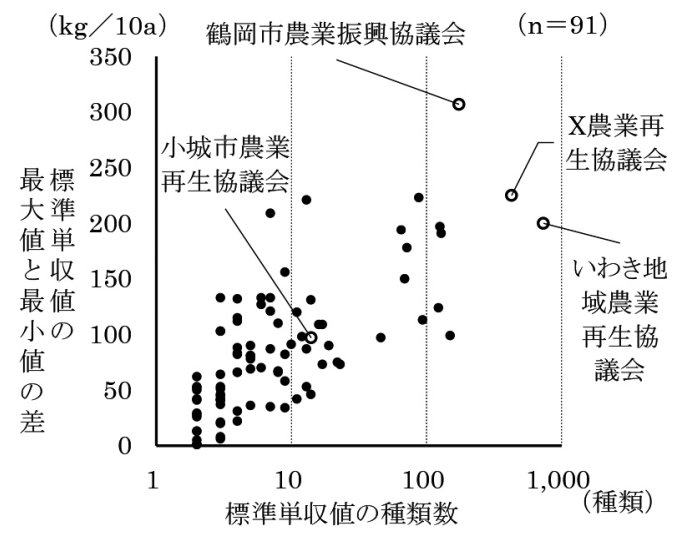

図 1. 標準単収值（複数設定）の種類数とレンジ 資料 : 表 1 と同じ.

標準単収值は非公表事項であることを踏まえて, アンヶート調査では回収率向上のため,「統一設定」 に関する細かな理由や設定方法を設問項目としな かったため詳細な実態は不明である。とはいえ,「統 一設定」された標準単收值が, 市町村別単収や都道 府県別単收と大きな差がみられないことから，その 設定方法は, 各地域の当年単収值や平年単収值等々 いった，市町村別単收や都道府県別単収と整合的な データを基に算出されているものと考兄られる.

\section{（3）標準単収值「複数設定」の特徵}

「複数設定」のらち, 標準単収值の種類数, 最大 値, 最小値を回答した 91 の地域農業再生協議会につ いて, 標準単收值の種類数と, 最大值と最小值の差 （レンジ）を図 1 に示した. 白丸で示した地域農業再 生協議会は 4 節で取り上げる事例を示している.

図 1 からは, 標準単収值の種類数が増光るほどレ ンジが大きくなる傾向が指摘できる。 また，種類数 
は 10 種類未満が多い一方, 100 種類を超える地域も 複数存在しており, 設定の種類数は多様である.

具体的には, 2 10 種類が 63 地域農業再生協議会 でレンジの平均が $61 \mathrm{~kg} / 10 \mathrm{a}, 11 \sim 100$ 種類が 21 地 域農業再生協議会でレンジの平均が $114 \mathrm{~kg} / 10 \mathrm{a}, 101$ ～1000 種類が 7 地域農業再生協議会でレンジの平均 が 192 kg/10 a，であった.

複数設定した理由について，アンケート調査では 回収率向上のため細かな設問項目とせず，先行研究 の知見を参考に選択肢(1)「協議会の対象範囲が広く， 地区ごとに単収の差が大きいから」, 選択肢(2)「低単 收な地域や圃場でも飼料用米や米粉用米の生産が不 利にならないようにするため」, 選択肢(3「その他」, 大まかな選択肢（複数回答可）を設定した. その結 果，選択肢(1)が最も多く 84, 選択肢(2)が 23, 選択 肢(3) 27 であった.「複数設定」する地域農業再生 協議会では，管内の地理的範囲が広いことを理由に している場合が多いといえる.

管内の地理的範囲が広いことによって地域内での 単収のばらつきが出やすいことも想定されるため, 選択肢(1)と選択肢(2)は類似した内容であるともいえ るが，選択肢(1)を選択した地域農業再生協議会の $75 \%$ に当たる 63 が選択肢(1)のみを選択して扣り， 選択肢(1)(2)を両方選択した地域農業再生協議会が 15 にとどまった。 このよらに，管内の地理的範囲が 広い場合でも, 単収差に対する条件不利補正が必ず しも意識されていない場合が多いといえる. 一方で, 選択肢(2)を単独で選択した地域農業再生協議会は 7 あり，低単収な地域や圃場でも飼料用米や米粉用米 の生産が不利にならないよらに意識的に条件不利補 正されている地域があることが確認できる.

また，選択肢(3)「その他」を選んだ調査対象のら ち, その詳細を自由記述解答した 27 にいて整理し たところ, 市町村別, 地区・集落別, 経営体別, 品 種別，栽培方法別，等の設定方法のあることが明ら かになった，具体的には以下の通りである.

市町村別の場合は, 市町村単位で統一した標準単 収值を設定する方法であり 8 地域農業再生協議会か ら回答を得た. 数值の決定は, 農政局や都道府県, 都道府県農業再生協議会が示す単収值を用いるとし ている.こうした方法は，「統一設定」と同様である が, 地域農業再生協議会が複数市町村を含むため結
果的に複数設定になったケースといえる.

地区・集落別の場合は，8 地域農業再生協議会か ら回答があり，とくに中山間地域と平場地域との単 収条件格差の是正を理由としている。またより細 かく経営体別に設定する地域農業再生協議会では, 対象戸数の多さや経営体ごとに単収が異なることを 理由に挙げていた。

栽培に関しては，1 地域農業再生協議会ではある が, 品種別（らるち品種，もち品種）に設定する場 合があるほか, 栽培方法（慣行栽培，有機栽培，直 播栽培, 湛水栽培) ごと標準単収值を設定する地域 農業再生協議会が 3 あった。

以上の設定方法は，それぞれ単独ではなく，組み 合わせて設定される場合も確認された.

\section{（4）「統一設定」と「複数設定」の比較}

本節（1）〜（3）を整理すると，現行政策に扣い て標準単収值は, 各地域農業再生協議会が定めるこ ととされているなか，運用実態では「統一設定」と 「複数設定」に大別されるといえる.

このらち，「統一設定」および市町村別で「複数設 定」する場合には，農政局や都道府県，都道府県農 業再生協議会が示す市町村別単収等のデータを標準 単収値の算出にそのまま活用していると考えられる.

他方，市町村別での設定を除く「複数設定」の場 合では, 地区・集落, 圃場, 生産者, 品種, 栽培方 法等の単収差につながる要素に着目し，その上で, これらの差異による単収格差の是正しょらと「複数 設定」するケースがみられた点が特徴である.

いずれの場合も, 各地域農業再生協議会が標準単 収值を定めて扣り，運用上の問題はないものの，標 準単収值の算出に当たっては，既存データを受動的 に使用する場合と，生産条件の不利を是正しょうと 能動的に設定している場合の 2 通りがあるといえる.

前者について，例えば，標準単収值の設定方法を 「その他」と回答した地域農業再生協議会の中には, 「県で設定する」，「県に設定させられる」と回答した 地域農業再生協議会もあり，都道府県段階の方針を 受動的に受け止めている地域農業再生協議会が存在 している実態がある.

すなわち，現行政策において標準単収值の設定方 法は各地域農業再生協議会に裁量があるものの, 各 地域農業再生協議会が必ずしも自律的に標準単収值 
表 3. 事例調査の対象と結果

\begin{tabular}{|c|c|c|c|c|c|}
\hline & & $\begin{array}{c}\text { いわき地域農業再生協 } \\
\text { 議会 }\end{array}$ & 鶴岡市農業振興協議会 & 小城市農業再生協議会 & $\mathrm{X}$ 地域農業再生協議会 \\
\hline \multicolumn{2}{|r|}{ 範囲（属人） } & 福島県いわき市内 & 山形県鶴岡市内 & 佐賀県小城市内 & 北陸 1 市町村内 \\
\hline & 転作(1) & 816 ha & 3,665 ha & 1,058 ha & 1,849 ha \\
\hline & $\begin{array}{l}\text { 飼料用米・ } \\
\text { 米粉用米(2) }\end{array}$ & 570 ha & 527 ha & 66 ha & 364 ha \\
\hline & (1)/(2) & $69.9 \%$ & $14.4 \%$ & $6.2 \%$ & $19.7 \%$ \\
\hline \multirow{4}{*}{$\begin{array}{l}\text { 標 } \\
\text { 準 } \\
\text { 単 } \\
\text { 收 } \\
\text { 值 }\end{array}$} & 種類 & 733 種類 & 174 種類 & 14 種類 & 426 種類 \\
\hline & 最大值(3) & $603 \mathrm{~kg} / 10 \mathrm{a}$ & $611 \mathrm{~kg} / 10 \mathrm{a}$ & $554 \mathrm{~kg} / 10 \mathrm{a}$ & $577 \mathrm{~kg} / 10 \mathrm{a}$ \\
\hline & 最小值(4) & $403 \mathrm{~kg} / 10 \mathrm{a}$ & $304 \mathrm{~kg} / 10 \mathrm{a}$ & $457 \mathrm{~kg} / 10 \mathrm{a}$ & $352 \mathrm{~kg} / 10 \mathrm{a}$ \\
\hline & (3)-(4) & $200 \mathrm{~kg} / 10 \mathrm{a}$ & $307 \mathrm{~kg} / 10 \mathrm{a}$ & $97 \mathrm{~kg} / 10 \mathrm{a}$ & $225 \mathrm{~kg} / 10 \mathrm{a}$ \\
\hline \multirow{3}{*}{$\begin{array}{l}\text { 標 } \\
\text { 隻 } \\
\text { 単 } \\
\text { 值 } \\
\text { 分 } \\
\text { 設 } \\
\text { 定 }\end{array}$} & 単位 & 農事組合 & 農業経営体 & 地区・集落 & 集落 \\
\hline & 設定方法 & $\begin{array}{l}\text { 農業共済が設定する農 } \\
\text { 事組合別単収にふるい } \\
\text { 目補正等を行う2). 農 } \\
\text { 政局が提示する単収や } \\
\text { 作況を踏まえて補正. }\end{array}$ & $\begin{array}{l}\text { 農業経営体別の前年の水 } \\
\text { 稲作付戋場ごとに, 農業共 } \\
\text { 済組合が設定する収量等 } \\
\text { 級 }(1 \text { 筆単位 }) \text { から加重平 } \\
\text { 均值を算出し, ふるい目補 } \\
\text { 正 }(1.8 \mathrm{~mm} \rightarrow 1.7 \mathrm{~mm}) し \\
\text { て算出. 農政局が提示する } \\
\text { 単収や作況による補正. }\end{array}$ & $\begin{array}{l}\text { 旧小城町, 旧三日月町は集 } \\
\text { 落単位で算出し, 旧牛津 } \\
\text { 町, 旧芦刈町は旧町単位で } \\
\text { 設定. 農業共済組合が設定 } \\
\text { する集落単収の值に, ふる } \\
\text { い目補正（1.8 mm } \rightarrow \\
1.7 \mathrm{~mm}) し, \text { 農政局が提 } \\
\text { 示する単収や作況による } \\
\text { 補正. }\end{array}$ & $\begin{array}{l}\text { 農業共済組合が設定 } \\
\text { する集落単収を用い } \\
\text { て算出した後, 農政局 } \\
\text { が提示する単収や作 } \\
\text { 況による補正. }\end{array}$ \\
\hline & 背景 • 理由 & $\begin{array}{l}\text { 市が広域, かつ高低差 } \\
\text { が大きいため, 主食用 } \\
\text { 米の配分を農事組合別 } \\
\text { に算出していた. 米粉 } \\
\text { 用米・飼料用米は, 主 } \\
\text { 食用米に準じて農事組 } \\
\text { 合別に設定. }\end{array}$ & $\begin{array}{l}2005 \text { 年に } 1 \text { 市 } 4 \text { 町 } 1 \text { 村が } \\
\text { 合併した際に, 米生産調整 } \\
\text { の不公平感を解消寸るた } \\
\text { め農業経営体別単収を導 } \\
\text { 入. 米粉用米・飼料用米 } \\
\text { は, 主食用米に準じて農業 } \\
\text { 経営体別単収を設定. }\end{array}$ & $\begin{array}{l}\text { 中山間地域と平場地域や, } \\
\text { 集落別の生産性格差を踏 } \\
\text { まえて設定. } 2005 \text { 年に } 4 \\
\text { 町が合併した際に, 各町の } \\
\text { 主食用米の配分方法が引 } \\
\text { き継がれた. 米粉用米・飼 } \\
\text { 料用米は, 主食用米に準じ } \\
\text { て地区別・集落別に設定. }\end{array}$ & $\begin{array}{l}\text { 中山間地域と平場地 } \\
\text { 域や, 集落別の生産性 } \\
\text { 格差を踏まえて設定. }\end{array}$ \\
\hline
\end{tabular}

資料：転作状況は農林水産省「地域農業再生協議会別の作付状況」（2018 年 9 月 28 日公表）より筆者作成. その他は, アン ケート調査結果および各地域農業再生協議会事務局）への聞き取り調査結果より筆者作成.

1）転作面積は，加工用米，備蓄米，新規需要米，麦，大豆，飼料作物，ソバ，ナタネの基幹作物を合計した作付面積であ る. 農林水産省「地域農業再生協議会別の作付状況」のデータの特徵は，表 2 注 2 を参照されたい.

2）詳しい計算式は，本文中に記載した.

を設定しているわけではないといえる。またこう した状況が，「統一設定」扔よび市町村別で「複数設 定」する場合に行われていると仮定すれば,「統一設 定」の地域で生産された飼料用米・米粉用米が約 7 割を占める現状に招いて，ほとんどの地域農業再生 協議会が自律的に標準単収值を設定しているわけで はないといえる.

以上より,「複数設定」は特殊なケースと考光ら光 るが，その実態を明らかにするため，4 節では，図 1 にて特に種類数の多い, いわき市地域農業再生協 議会, 鶴岡市農業再生協議会, 北陸地方 X 地域農業 再生協議会の事例，拉よび設定方法に打いて旧市町
村別と集落別を組み合わせる特徵をもつ小城市農業 再生協議会の事例に着目する。 これらの事例は,「統 一設定」扣よび市町村別で「複数設定」する地域農 業再生協議会が多い中で, 限定的な事例であり,「複 数設定」の場合の特徵がより表出しやすいと考劣て 選定したものである.

\section{4 事例にみる標準単収值の複数設定の詳細 (1) 事例調査対象の概況}

事例調査の調査対象の概況と, 標準単収値の設定 状況を表 3 に示した.

転作状況でみると，標準単收值が最も多いいわき 
市地域農業再生協議会では, 飼料用米と米粉用米が 転作の 69.9\%を占めて打り特徵的である。こ秃は東 日本大震災の被災戋場での飼料用米生産が推進され ていることも背景にあるため例外的と考光られるが, その他の事例のみを比較した場合でも, 標準単収值 の種類が多いほど, 転作に占める飼料用米と米粉用 米の割合が高い.

もっとも,「統一設定」の場合でも，これら 4 事例 よりる飼料用米や米粉用米による転作が盛んな地域 があるため, 標準単収值の種類数が多い注ど飼料用 米や米粉用米による転作が進みやすいとはい方ない. とはい光, 本研究での事例調査対象に限れば, 同じ 「複数設定」の場合でも標準単收值の種類が多いほ ど，飼料用米と米粉用米による転作が進む割合が高 い傾向が示唆される.

\section{（2）標準単収値の設定方法にみる各事例の共通点}

標準単收値の設定方法は，それぞれ異なるが，方 法や背景・理由には共通点がみられる.

まず, 設定方法の共通点は, (1)農業共済組合のデー 夕活用, (2)ふるい目補正, (3)農政局の提示する単収 と一致するよう補正，といら点である.

具体的な計算方法は事例によって異なるが，たと えばいわき市地域農業再生協議会に招いては，いわ き市の平均収量（7 中 5) に, 「統計補正係数」を乗 じて補正した単収值を「ふるい目換算後単収值」で 除して算出する. この際, 統計補正係数とは合理的 単収を算出するためのものであり, 当年産地带別 (福 島県浜通り）の平年収量から作柄表示地带別（福島 県浜通り）収量（7中 5) を除したものである。ま た, ふるい目換算後単収值は, 農業共済組合が定め る農事組合別の水稲共済単収から，(1-地域別の 1.7 $\sim 1.8 \mathrm{~mm}$ の平均重量割合）を除して求めている.

次に, 標準単收值を「複数設定」する背景・理由 の共通点は, (1)地域間の生産性格差の補正, (2)主食 用米での取り組みに準じた設定，といら点である。

例えば，鶴岡市農業再生協議会の場合，2005 年に 1 市 4 町 1 村が合併した際に, 米生産調整に伴う主 食用米の配分をめぐって市で統一した単収值に基づ く配分はもちろん, 旧市町村別単収值で配分を行ら と不公平感があるため, 農業経営体別単収に基づい て配分することにした経緯がある. 米粉用米・飼料 用米は，こうした主食用米の配分をめぐる設定方法
に準じて農業経営体別に標準単收值が設定されてい る. 算出方法も稲作の生産実績と農業共済組合が設 定する収量等級に基づく加重平均値を用いており, 生産戋場・面積の実態に即した值に設定されている.

また，小城市農業再生協議会では，2005 年に 4 町 が合併した際に, 各町の主食用米の配分方法が引き 継がれ, 平場地域であり単収格差の少ない旧牛津町, 旧芦刈町は旧町単位で算出し, 中山間地域を含を等, 単收格差が大きい旧小城町，旧三日月町は集落単位 で算出することとなって現在に至る。この方法を米 粉用米・飼料用米にも応用したため, 主食用米の配 分と同様に，標準単收值は旧町別と集落別の設定方 法が並存している.

以上のように, 調査対象の 4 事例に打いては, い ずれも米粉用米・飼料用米の数量払いに伴って独自 に標準単收值の設定方法を決めたものはなく，主食 用米の配分をめぐる生産者間の不公平感を是正する 従来の取組の延長として複数の標準単収值が設定さ れていることが実態調査から明らかになった。

\section{5. 結果と政策的含意 (1) 本研究の結果}

本研究の結果, 標準単収值を「統一設定」してい る地域農業再生協議会は $61 \%$ であり, 平均值は $513.1 \mathrm{~kg} / 10 \mathrm{a}$ であった。他方, 標準単収值を複数種 類に設定した地域において, 最高值と最低值の差は, $2 \sim 10$ 種類が平均 $61 \mathrm{~kg} / 10 \mathrm{a}, 11 \sim 100$ 種類が平均 $114 \mathrm{~kg} / 10 \mathrm{a}, \quad 101 \sim 1000$ 種類が平均 $192 \mathrm{~kg} / 10 \mathrm{a}$ ，で あり, 幅広い単収值に対応するほど標準単收値の種 類数が増える傾向がみられた.

こらした標準単収值の設定は, いずれも現行政策 に従って各地域農業再生協議会が定めているもので あるが，その実態は受動的に設定しているケースと， 能動的に設定しているケースに大別されることが, アンケート調査結果から明らかとなった.

後者については，標準単収値の設定方法やその背 景について, 市町村別, 地区・集落別, 経営体別, 品種別，栽培方法別，等による単収条件格差の是正 を目的としていることが，アンケート調査結果捛よ び聞き取り調査した 4 事例の結果より明らかになっ た.この際, 事例分析の結果として特徵的な点は, 主食用米の配分をめぐる生産者間の不公平感を是正 
表 4. 単収実績と標準単収值が一致した場合の受給交付金額（10 a 当たり）

\begin{tabular}{|c|c|c|c|c|}
\hline & $\begin{array}{l}\text { いわき地域農 } \\
\text { 業再生協議会 }\end{array}$ & $\begin{array}{c}\text { 鶴岡市農業振 } \\
\text { 興協議会 }\end{array}$ & $\begin{array}{c}\text { 小城市農業再 } \\
\text { 生協議会 }\end{array}$ & $\begin{array}{c}\mathrm{X} \text { 農業再生協 } \\
\text { 議会 }\end{array}$ \\
\hline 2017 年産主食用米単収（1)） & $510 \mathrm{~kg}$ & $590 \mathrm{~kg}$ & $549 \mathrm{~kg}$ & $540 \mathrm{~kg}$ \\
\hline 2018 年産標準単収値（2)） & $403 \sim 603 \mathrm{~kg}$ & $304 \sim 611 \mathrm{~kg}$ & $457 \sim 554 \mathrm{~kg}$ & $352 \sim 577 \mathrm{~kg}$ \\
\hline 標準単収值が(2)の最大值，単収が(2)の最大值の場合（A） & 80,000 円 & 80,000 円 & 80,000 円 & 80,000 円 \\
\hline 標準単収值が(1)，単収が(2)の最大值の場合（B） & 95,531 円 & 83,507 円 & 80,835 円 & 86,179 円 \\
\hline $\mathrm{A}-\mathrm{B}$ & $-15,531$ 円 & $-3,507$ 円 & -835 円 & $-6,179$ 円 \\
\hline 標準単収値が(2)の最小値, 単収が(2)の最小値の場合（a) & 80,000 円 & 80,000 円 & 80,000 円 & 80,000 円 \\
\hline 標準単収值が(1)，単収が(2)の最小值の場合（b） & 62,131 円 & 55,000 円 & 64,636 円 & 55,000 円 \\
\hline$a-b$ & 17,869 円 & 25,000 円 & 15,364 円 & 25,000 円 \\
\hline
\end{tabular}

資料: 表 3 と同じ.

する従来の取組の延長として標準単収值が「複数設 定」されている点である.

4 事例は，主食用米の配分をめぐる従来の取組と して，農業経営体への配分量を算出寸る際に用いる 単収值を統一して設定するょりも，より細かく地区 別や戋場別に設定することで, 農業経営体間の不公 平感を是正してきた地域であり，その方法に準じて 標準単収值が設定されていたのである.

市町村別に「複数設定」する場合に加えて，これ ら 4 事例が「複数設定」に至る経緯が一般的である ならば, 標準単収值を能動的に「複数設定」するケー スは一般的に, 飼料用米と米粉用米に対する数量払 いの導入を機に, 標準単収值の算出方法を検討した ものではなく, 従来の主食用米の配分方法を援用し て「複数設定」しているケースが少なくないと推察 される.

\section{（2）政策的含意}

本研究では, 標準単収值の設定実態として,「統一 設定」や市町村別の「複数設定」のように, 市町村 単位程度の面的広がりで設定されているケースが多 いことが明らかになった.「複数設定」は, 飼料用米 と米粉用米の生産面積シェアにおいて $26 \%$ 占める が，このらち市町村別に「複数設定」しているケー スを除けばさらにシェア率は低くなると考兄られ， 飼料用米と米粉用米の生産の現状として, 約 $7 \sim 8$ 割 は市町村単位程度の面的広がりで設定されているも のと考光られる.

こうした実態は，大澤が全農林労働組合（2012： 23）で述べたような，かつて農林水産省で検討され た全国統一的な単收設定というほど画一的ではない.
とはいえ, 個別の農業経営体にとって, 市町村単位 レベルで標準単收值が画一化されることは, 地区・ 集落, 経営体, 品種, 栽培方法の差異を要因とする 単收格差を背景とした交付金受給額の格差が配慮さ れにくい制度的条件となっていることを指摘できる。

例えば，聞き取り調査した 4 事例において，標準 単收值が最大値となる最優良地と, 逆に最小值とな る最劣等地とでは，標準単收値の設定方法の違いに より受給する交付金額は異なる。これを試算したの が表 4 である.ここでは，アンケート調査結果を踏 まえて, 2017 年産米主食用米単収で標準単收值を 「統一設定」した場合と，各地域で実際に 2018 年産 に颃いて「複数設定」された標準単収值を用いて, 現行の数量払い（区分管理）の交付金額（数量払い の傾斜 167 円 $/ \mathrm{kg}$, 交付上下限 55,000 105,000 円/10a）を踏まえて算出した。な拉，ふるい目補正 等は無視し, 単純に補助金と標準単收值との関係を 示している.

最優良地で生産する場合は,「複数設定」の方が 「統一設定」と比較して交付金額は低下寸る. 他方, 最劣等地で生産する場合には，「複数設定」の方が 「統一設定」と比較して交付金額は増加する。このよ らに「複数設定」は同じ市町村内の中でも単収条件 が不利な圃場に考慮された交付金額に是正されてい る. 例光ば, 鶴岡市やX 農業再生協議会は「複数設 定」することによって，「統一設定」した場合と比較 して，25,000 円/10 a に相当する支援措置になってい ると指摘できる.

以上を逆に考光ていくと，「複数設定」ではなく 「統一設定」することで，より高単收な圃場流ど交付 
金の受給額が増加する，例えば，いわき市に打いて 「統一設定」された場合には, 最優良地では前年の主 食用米単収の水準を收穫しても 95,531 円/10 a を受 給できるのに対して, 再劣等地では前年の主食用米 単収の水準を收穫するだけでは 62,131 円/10 a にしか ならず, 単収格差が交付金額の差額 33,400 円/10 a に 反映されるのである.

したがって, 全国の地域農業再生協議会のらち約 7〜8 割は市町村単位程度の面的広がりで設定されて いると考えられることを踏まえるならば，現状では， より生産性が高い固場, 地区での飼料用米や米粉用 米の生産振興に貢献しているのである.このため, より広域な標準単収值の統一は, 高単収地域におい て飼料用米や米粉用米が，他の米と競合したり，低 単收地域に扣沙る飼料用米や米粉用米の生産が阻害 されたりしている要因の一つであると指摘できる.

また「複数設定」の場合には, 従来の主食用米生 産時の単収格差が, 飼料用米や米粉用米生産による 交付金受給を介して条件不利性が緩和されていると 考えられ, 耕境に近い最劣等地の圃場や, 収益性や 地代に影響を与えていると考えられる.

以上のよらに，努力が報われる仕組みとして謳わ れる数量払いであるが,「統一設定」の場合, 平年並 みに生産した際の交付金額が個別経営間で異なるた め, 同じ交付金額を得る場合でも求められる努力の 程度や, 制度的環境が異なる. 数量払いは, 捨て作 りの抑制や個別経営の増収意欲の促進といった個別 経営レベルに焦点が当てられている一方で, 現場の 標準単収值の設定方法いかんによって地域選別的な 側面ももつのである.

こうした特徵を持つ標準単収值について, 国は設
定方法を各地域に委ねている。このため，どのよう な圑場で飼料用米や米粉用米を振興するかを検討す ることが各地域に問われている構造といえる。

本研究の分析結果より「統一設定」が全国的に多 いことや，「統一設定」の場合，劣等地よりも優等地 の方が飼料用米や米粉用米の生産に取り組みやすい 制度的環境であることが明らかとなった。

他方で, 標準単収值の設定は耕境にお打る営農継 続条件にも直結する.地域農業再生協議会が主体と なり標準単收值を細かく「複数設定」することによっ て, 固場や地区の間の生産性格差が戦略作物助成の 交付額に影響を与えないよらに補正することが可能 であり, 農家の単収向上の努力を優等地から劣等地 まで公平に評価する制度として戦略作物助成を運用 できる. 標準単収值について,「複数設定」する 4 事 例では, 従来の主食用米の配分方法を援用して設定 されていたが, 不作付け水田を課題とする地域では, 劣等地の水田保全・活用の観点を取り入れた戦略的 な設定も検討されてょいと考光られる.

付記

本研究は JSPS 科研費（19K15933）の研究成果で ある.

\section{引用文献}

鵜川洋樹・高津英俊・山本麻貴（2019）「飼料用米生産に打け る数量払い導入と単収変動」『農業経営研究』57(2) : 59-64. 小川真如 (2017) 『水稲の飼料利用の展開構造』日本評論社. 宮田剛志（2010）「モデル対策下の飼料用米・飼料用稲の到達 点と課題」『農業と経済』76(13) : 29-39.

全農林労働組合 (2012)「研究会 : 平成 23 年度食料・農業・農 村白書をめぐって」『農村と都市をむすぶ』62(8)：4-49. 